\title{
PPARY activation serves as therapeutic strategy against bladder cancer via inhibiting PI3K-Akt signaling pathway
}

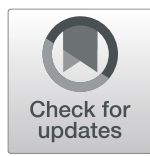

Shidong Lv ${ }^{1+}$, Wei Wang ${ }^{2+}$, Hongyi Wang ${ }^{1}$, Yongtong Zhu ${ }^{3}$ and Chengyong Lei ${ }^{1^{*}}$

\begin{abstract}
Background: Heterogeneity in bladder cancer results in variable clinical outcomes, posing challenges for clinical management of this malignancy. Recent studies suggest both tumor suppressive and oncogenic role of PPARY in bladder cancer. The fuction of PPARY signaling pathway in modulating carcinogenesis is controversial.

Methods: The expression of PPARY and association with overall survival were analyzed in patients from two cohorts. The effect of PPARY activation on cell proliferation, cell cycle, and cell apoptosis were determined with the agonists (rosiglitazone and pioglitazone), the inverse agonist (T0070907), and the antagonist (GW9662) in Umuc-3 and 5637 bladder cancer cells. The correlation of PPARY activation with PI3K-Akt pathway was evaluated with RNA sequencing data from the TCGA cases and 30 human bladder cancer cell lines. The effect of PPARY activation on tumor growth was validated with subcutaneous tumor models in vivo. The effect of PPARY activation on PI3K-Akt signaling transduction was determined with multiple assays including immunohistochemistry, flow cytometry, proteomic array, and western blotting.
\end{abstract}

Results: We showed that PPARY was a favorable prognostic factor in patients with bladder cancer. PPARY activation by rosiglitazone and pioglitazone markedly induced cell cycle G2 arrest and apoptosis in bladder cancer cells, which resulted in inhibition of cell proliferation in vitro and suppression of tumor growth in vivo. The underlying mechanism involved marked inhibition of PI3K-Akt pathway.

Conclusions: This study reported the tumor-suppressive effect of PPARY agonists in bladder cancer, suggesting that transactivation of PPARY could be served as a potential strategy for the chemoprevention and therapeutic treatment of bladder cancer.

Keywords: Bladder cancer, PPARY, PI3K, Akt, Apoptosis

\section{Background}

Bladder cancer is the ninth most common type of cancer worldwide, which affects nearly 3.4 million people with 430,000 new cases in 2015 [1]. The highest incidence and mortality are found in North America and Europe, but bladder cancer are increasing in some eastern European and developing countries [2]. Though superficial (non-invasive) urothelial carcinoma with a 5-year survival rate of $96 \%$ constitutes the major portion (75\%) of bladder cancer cases, patients diagnosed with muscle-invasive bladder cancer

\footnotetext{
* Correspondence: Icy_fimmu@126.com

†'Shidong Lv and Wei Wang contributed equally to this work.

'Department of Urology, Nanfang Hospital, Southern Medical University,

No.1838 North of Guangzhou Avenue, Guangzhou 510515, China

Full list of author information is available at the end of the article
}

(MIBC) havevery poor prognosis, with a 5-year survival rate of $35-70 \%$. Heterogeneity in MIBC results in variable clinical outcomes, posing challenges for clinical management of this aggressive malignancy. In recent years, studies are dedicated to discover the intrinsic molecular subtypes of bladder cancer with particular phenotypic characteristics [3-5]. For example, the frequency of FGFR3 alterations in luminal-papillary subtype (35\%) suggests that tyrosine kinase inhibitors of FGFR3 may be an effective therapeutic approach [6]. Most recently, a multiplatform analysis of MIBC patients provided insights into mutational profiles with prognostic value and established a framework associating distinct tumor subtypes with clinical options [7]. These studies have expanded our understanding of this malignancy and 
provided insights for developing personalized therapies. However, experimental data validating the contribution of these molecular signatures to informing clinical trial designs are limited.

Peroxisome Proliferator Activated Receptor Gamma (PPARG) is a member of the nuclear receptor superfamily that functions as a ligand-activated nuclear receptor that regulates glucose and lipid metabolism, inflammation, and cellular growth and differentiation. Accumulating evidence implicates PPARG as a key gene in bladder cancer development; however, observations regarding the functional effect of PPARG alteration on the development of bladder cancer are controversial. It was reported that luminal MIBCs are enriched with activating FGFR3 and ERBB3 mutations and ERBB2 amplifications, and their gene expression profiles are controlled by PPAR $\gamma$ (the protein name of PPARG), suggesting the pro-tumorigenic role in luminal tumors [3, $4,7,8]$. In addition, overexpression of GATA3 and FOXA1 may cooperate with PPAR $y$ activation to drive trans-differentiation of a basal bladder cancer cells to a luminal phenotype [9]. Higher expression of PPAR $\gamma$ or its activation by agonists promotes bladder cancer cell migration and invasion [10]. Another in vitro study also showed that reducing PPARyactivity through pharmacologic inhibition or genetic ablation inhibited proliferation of PPAR $\gamma$-activated bladder cancer cells [11]. On the contrary, multiple studies have indicated that PPAR $\gamma$ activation might be also a promising approach to suppress bladder cancer. By activating PPAR $\gamma$, simvastatin inhibited bladder cancer cell proliferation and induced cell cycle arrest at G1/ G0 phase [12]. The PPAR $\gamma$ agonist troglitazone induces autophagy, apoptosis and necroptosis in bladder cancer cells [13]. In aggregate, PPAR $\gamma$ plays a crucial role in driving cell biology and it is emerging as a promising therapeutic target; however, inconsistent conclusions highlight the urgent need to decipher the underlying mechanism for the diverse characters of PPAR $\gamma$ in modulating bladder cancer.

In the present study, we investigated the association of PPAR $\gamma$ expression with the prognosis of patients from bladder cancer cohorts. The functional effects of PPAR $\gamma$ on cell proliferation, cell cycle and apoptosis were determined in human bladder cancer cells with pharmacological activation and inhibition of PPAR $\gamma$. The inverse correlation between PPARyactivation and PI3K-Akt signaling pathway was identified with bioinformatics analysis on the The Cancer Genome Atlas (TCGA) datasets and 30 bladder cancer cell lines. The molecular findings were further investigated with human bladder cancer cells as well as subcutaneous tumor model in vivo.

\section{Methods}

\section{Reagents}

Primary antibodies detecting PPAR $\gamma$, Phosphatase and tensin homolog (PTEN), phospho-Akt (Ser473), p21 Waf1/
Cip1, phospho-Bad (Ser136), Phospho-FoxO1 (Ser256), Phospho-Bcl2 (Ser70), and HRP-labeled secondary antibodies were purchased from Cell Signaling Technology (MA, USA). Antibodies detecting phospho-Akt (Ser473) and PPAR $\gamma$ in the immunohistochemistry were purchased from LifeSpan (Seattle, WA, USA). The PPARyagonists rosiglitazone and pioglitazone, the inverse-agonist T0070907, and the antagonist GW9662 were purchased from Selleck Chemicals (TX, USA).

\section{Human bladder cancer tissue chip}

Human bladder cancer tissue microarray (TMA) chip (BlaU066Su01) containing normal mucosa (10 cases) and bladder cancer (56 cases) were obtained from Shanghai Biochip Company Ltd. (Shanghai, China). The information including patient survival and tumor stage has been provided in supplementary data (Additional file 1: Table S1). Samples for TMA were collected using $2.0 \mathrm{~mm}$ diameter core needles from a spot of tumors with the most representative histology of each surgical specimen. The clinicopathological and follow-up data of patients were prospectively collected at the Shanghai Eastern Hospital from February 2008 to March 2014. The whole images of histopathological and immunostaining slides were acquired with an Aperio VERSA scanning system (Leica Biosystems, IL, USA).

\section{Cell culture}

The human bladder cancer Umuc-3 cells (Catalog \# CRL-1749) was obtained from American Type Culture Collection (ATCC, VA, USA) and cultured in in McCoy's 5 a medium supplemented with $10 \%$ fetal bovine serum. The human bladder cancer 5637 cells (HTB-9, Catalog \# TCHu1) were purchased from the Cell Bank of Shanghai Institutes for Biological Sciences (Shanghai, China) and cultured in RPMI-1640 medium with 10\% fetal bovine serum. The cell lines have recently been tested for mycoplasma contamination and authenticated by Short Tandem Repeat (STR) profiling.

\section{Cell proliferation, cell cycle and apoptosis}

Umuc-3 cells and 5637 cells were seeded in multi-well plates and culture for $24 \mathrm{~h}$ before treatment. Cells were treated with rosiglitazone, pioglitazone, T0070907, and GW9662 (10 and $20 \mu \mathrm{M}$ ) for 48 to $96 \mathrm{~h}$. Cell Counting Kit-8 (CCK-8) (Sigma, MO, USA) was used for determining the proliferation of cells.

Flow cytometry was applied to analyze the cell cycle and apoptosis. After treatment, the cells were collected by trypsin digestion and fixed with $70 \%$ ethanol for $4 \mathrm{~h}$ at $4{ }^{\circ} \mathrm{C}$. Then the cells were washed and resuspended with $500 \mu \mathrm{l}$ of FxCycle PI/RNase Staining Solution (Invitrogen, Shanghai, China) and incubated in dark for 20 min at $37^{\circ} \mathrm{C}$. Cells were analyzed with FACSCalibur flow cytometer (BD Biosciences, CA, USA). Annexin V-FITC 
Apoptosis Detection Kit (BD Biosciences) was used for the determination of cell apoptosis according to the instruction of manufacture.

\section{Subcutaneous tumor model}

To establish the subcutaneous bladder tumor model, cultured Umuc-3 and 5637 cells were collected after trypsin digestion and suspended with fresh medium and Matrigel Basement Membrane Matrix (BD Biosciences), and then $10^{6}$ cells in $0.1 \mathrm{ml}$ were subcutaneously injected into the back of BALB/c athymic nude mice (6-week old, male). For each cell type, 14 animals were randomly devided into two groups with randomization schedules based on body weight. Rosiglitazone was intragastrically administered at $100 \mathrm{mg} / \mathrm{kg}$ BW twice a week for 4 weeks $(n=7)$. Animals in the control group $(n=7)$ were treated with the vehicle solvent (carboxymethylcellulose, $0.5 \% \mathrm{w} / \mathrm{v}$ ). Tumor volume was measured with caliper in two perpendicular diameters of the implant and calculated using formula $1 / 2 a \times b^{2}$, whereas the long diameter and $b$ is the short diameter. Tumor volume was measured once every 7 days. Animal were humanely sacrificed with $\mathrm{CO}_{2}$ anesthetization at Day 28. The subcutaneous tumors were removed and fixed in $10 \%$ neutral buffered formalin for pathological analysis and immunostaining.

\section{Immunohistochemical (IHC) staining and immunofluorescence staining}

Formalin-fixed tissues were embedded in paraffin for the preparation of $5 \mu \mathrm{m}$ tissue sections. After deparaffinize and rehydrate the sections, the slides were put in citrate buffer $(\mathrm{pH}=6.0)$ and boiled in a microwave so that antigens are retrieved for $20 \mathrm{~min}$ at $98{ }^{\circ} \mathrm{C}$. Then tissue sections were incubated with $3 \%$ hydrogen peroxide solution in methanol at room temperature for $10 \mathrm{~min}$ to block endogenous peroxidase activity. After blocking with $5 \%$ normal goat serum, the sections were incubated with primary antibody overnight at $4{ }^{\circ} \mathrm{C}$. Subsequently, the expression of antigens was visualized with SignalStain Boost Detection Reagent (Cell Signaling Technology) and diaminobenzidine (DAB) followed by the counter staining with hematoxylin. The IHC staining score was estimated for each sample with intensity value (negative, $0 ;+, 1 ;++, 2$; and,+++ 3 ) multiply positive rate value (negative, $0 ; 1-25 \%, 1 ; 26-50 \%, 2 ; 51-75 \%, 3$; and $76-100 \%, 4)$. Semi-quantitative comparision was analyzed according to the immunostaining score in different types of pathologic lesions.

For immunofluorescence staining, the cultured cells on cover slides were fixed with $4 \%$ paraformaldehyde for $15 \mathrm{~min}$ at room temperature. Then the cells were blocked with 5\% normal goat serum and then incubated with primary antibody overnight at $4{ }^{\circ} \mathrm{C}$, followed by Alexa Fluor 488 or 555 labelled secondary antibody
(Abcam, Shanghai, China). Nucleus was counterstained with DAPI (Cell Signaling Technology). The slides were observed and photographed under a fluorescence microscope (Leica DMRA, Wetzlar, Germany).

\section{Western blotting}

The whole cell proteins were isolated from bladder cancer cells. Protein sample mixtures were prepared with LDS Sample Buffer and separated by denaturing gel electrophoresis with the NuPAGE gels (Invitrogen). Then proteins were transferred from gel to a nitrocellulose or polyvinylidene fluoride (PVDF) membrane. After blocking with $5 \%$ skim milk, the membranes were incubated with primary antibodies. Beta-actin was used for normalization of protein loading. After incubation with HRP-labeled secondary antibody, the membranes were subsequently developed with Femto Chemiluminescent substrate (Thermo, MA, USA).

\section{Statistical analysis}

All data on cell proliferation, cell cycle and apoptosis rate represent at least three independent experiments and are expressed as mean \pm standard deviation. Statistical analysis were performed using one-way Analysis of Variance (ANOVA) followed by Bonferroni's test for multiple comparisons. $P$ value $<0.05$ was considered that the difference was statistically significant.

\section{Results}

\section{PPARy is a favorable prognostic factor in patients with bladder cancer}

In the tissue array of a retrospective cohort of 66 patients with bladder cancer, the protein level of PPARy expression was evaluated by immunohistochemistry staining. PPARY was highly expressed in para-cancer (normal) tissues, as a nuclear factor predominantly located in the nucleus of cells (Fig. 1a). In contrast, the expression of PPAR $\gamma$ was significantly decreased in the tumor tissues (Fig. 1a and b). The association between PPARy expression in tumors and the post-surgery overall survival was investigated. The cohort was divided into three groups according to the high-expression (33/66), medium expression (14/66) and low-expression (19/66) of PPARY (Fig. 1c). Patients survival analysis suggested that high-expression level of PPAR $\gamma$ was associated with longer survival time $(P=0.0024)$ (Fig. 1d).

To confirm this observation, we performed bioinformatics analysis on PPARG with 412 MIBC cases/patients from The Cancer Genome Atlas (TCGA) database. PPARG gene was altered in 86 (21\%) of 412 sequenced cases/patients, in which PPARG mRNA expression was dramatically increased $(P<1.12 \mathrm{e}-22)$ (Fig. 1e). The overexpression of PPARG was closely associated with the increased copy-number from genome identification of significant 


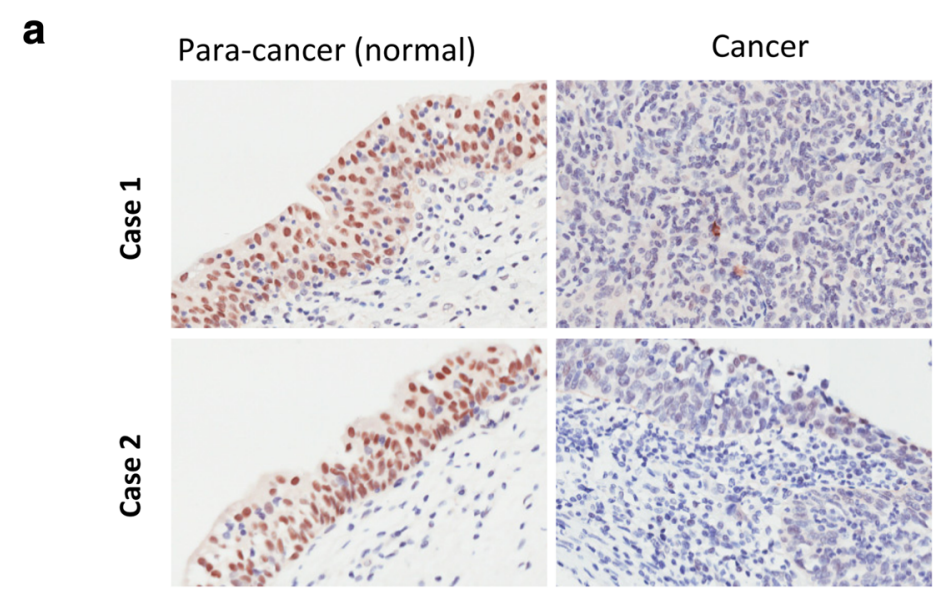

C

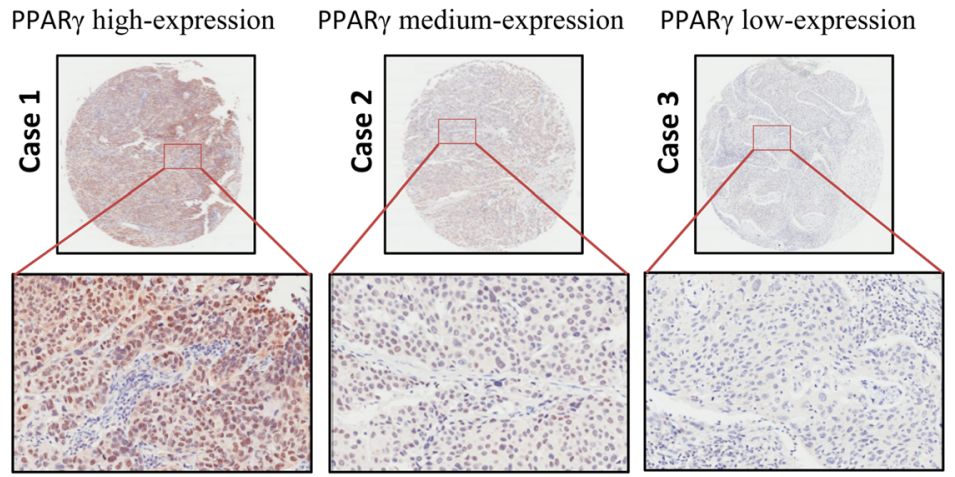

e

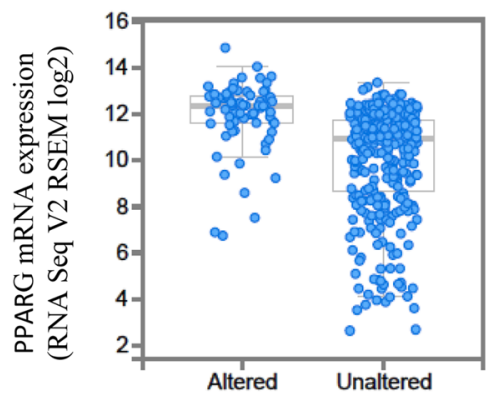

PPARG alteration $(\mathrm{P}<1.12 \mathrm{e}-22)$ f

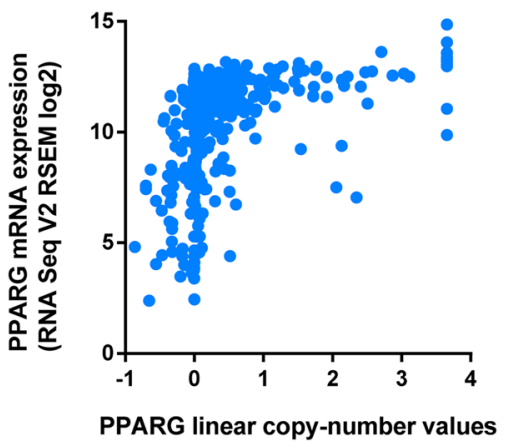

b

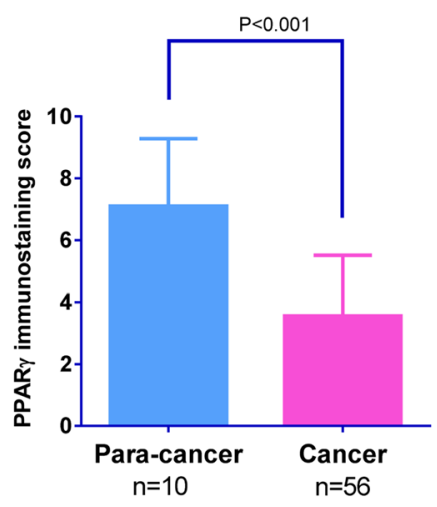

d

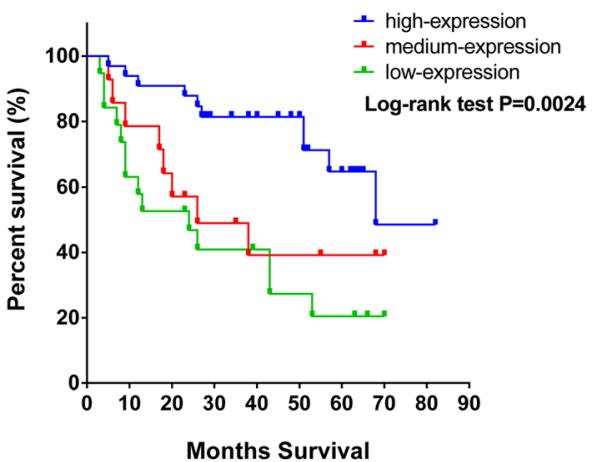

g

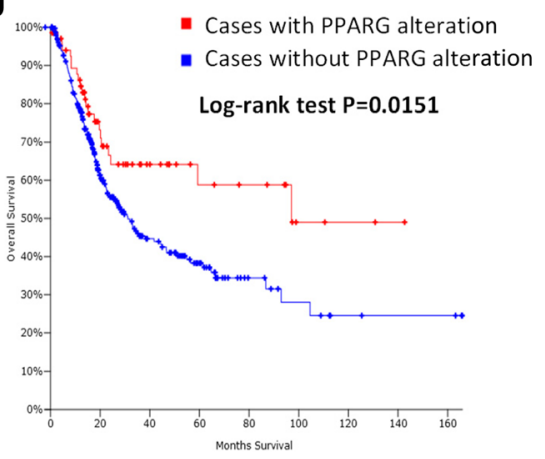

Fig. 1 PPARY is a favorable prognostic factor in patients with bladder cancer. (a) Expression of PPARy in para-cancer (normal) and cancer tissues determined with immunohistochemistry staining. (b) PPARy expression was lower in cancer tissues. (c) Different levels of PPARY expression in bladder cancer cases determined with immunohistochemistry staining. (d) Overall survival analysis in bladder cancer cohort $(n=66)$. (e)

Transcriptional alteration of PPARG mRNA determined by RNA-sequencing in TCGA MIBC cases. (f) Correlation of PPARG expression with linear copy-number. (d) Overall survival analysis on PPARG alteration in TCGA cohort $(n=412)$

targets in cancer (GISTIC) analysis (Fig. 1f). Importantly, the Overall Survival Kaplan-Meier Estimate indicated that MIBC patients with increased mRNA level of PPARG possess significantly longer survival period $(P=0.0151)$ (Fig. 1g), which is in line with the survival analysis on our cohort. In aggregate, these data suggested that PPAR $\gamma$ might be a favorable prognostic factor in bladder cancer patients.
PPAR $y$ activation suppresses proliferation of bladder cancer cells by inducing $\mathrm{G} 2$ phase cell cycle arrest and apoptosis

To determine the functional effect of PPARY in bladder cancer, we next tested the effect of pharmacologic activation and inhibition of PPARY on the cell growth in Umuc-3 and 5637 cells. In the both cell lines, T0070907, a PPARyinverse-agonist and GW9662, a PPARyantagonist 
were not able to induce significant inhibition of cell proliferation (Fig. 2a and b). However, the full PPARyagonists including pioglitazone and rosiglitazone significantly suppressed cell growth in Umuc-3 and 5637 cells (Fig. 2a and $b$ ), suggesting PPAR $\gamma$ activation suppresses proliferation of bladder cancer cells in vitro.

Next we determined the effect of PPARy activation or inhibition on the cell cycle progression of bladder cancer cells. In Umuc-3 and 5637 cells, pioglitazone and rosiglitazone markedly increased the proportion of G2 phase cells, however, cell population at G1 phase was not significantly altered (Fig. 3). The inhibition of PPARy by T0070907 and GW9662 did not induce significant change on cell cycle progression in these cells. In addition, PPAR $\gamma$ activation by pioglitazone and rosiglitazone dramatically increased the apoptosis in Umuc-3 and 5637 cells (Fig. 4). In contrast, T0070907 and GW9662 induced significant suppression of apoptosis in the bladder cancer cells. Taken together, these data indicated that PPAR $\gamma$ activation suppresses proliferation of bladder cancer cells by inducing G2 phase cell cycle arrest and apoptosis.

\section{PPARY activation inhibits phosphoinositide 3-kinase (PI3K) -Akt signaling pathway in bladder cancer}

We next analyzed the transcriptional impact of PPARG in the TCGA MIBC cohort by stratification into three major groups according to Neoplasm Disease Stage. We found that PPARG mRNA expression was in parallel with PPARy activation as indicated by the expression of its typical target genes including ACOX1, ACOXL, ACSM6, FBP1 and PLIN5. Interestingly, the expression of signature genes of PI3K-Akt signaling pathway was commonly up-regulated in the MIBC patients with low activation of PPAR $\gamma$ from different stages of bladder cancer (Fig. 5a). The inverse association was also observed from the RNA sequencing analysis with 30 human bladder cancer cell lines (Fig. 5b). These data suggests that the interaction of PPAR $r w i t h$ PI3K-Akt pathway may drive the pathogenesis of bladder cancer.

To decipher the correlation between PPARyand PI3K-Akt, we determined the effects of PPARy selective agonist (rosiglitazone) and the inverse-agonist (T0070907) on Akt phosphorylation/activation in 5637 cells. As shown in Fig. 5c, rosiglitazone induced significant inhibition of Akt phosphorylation (Ser473). In contrast, T0070907 dramatically promoted the activation of Akt. In addition, we further validated the effect of rosiglitazone and T0070907 on PI3K-Akt signaling activation with a protein array (Fig. 5d). In consistent with the Phos-flow assay, phosphorylation of Akt (Thr308 and Ser473) and its down-stream molecules including S6, PRAS40 and GSK-3 $\alpha$ was significantly repressed by rosiglitazone, however, enhance by T0070907

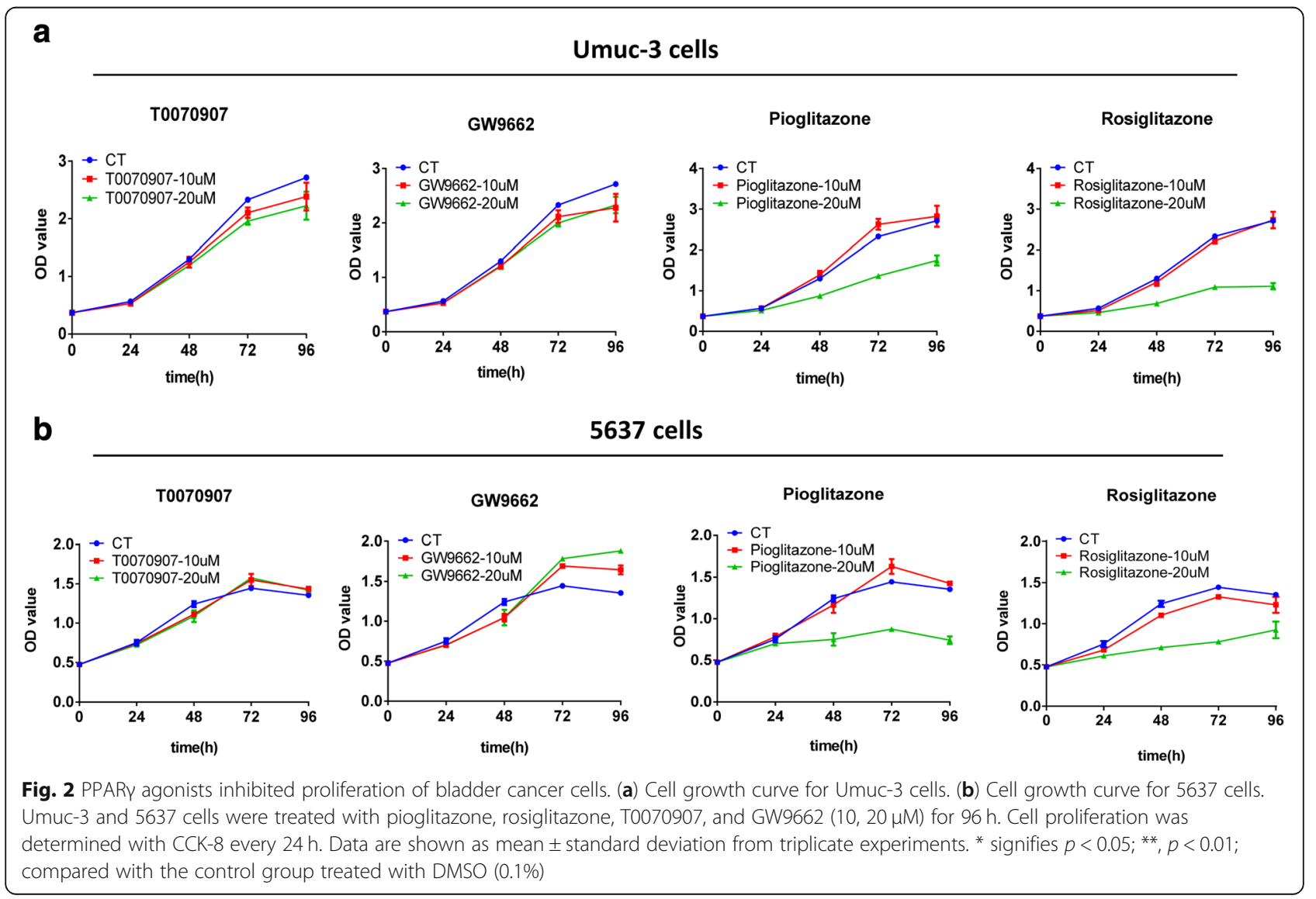




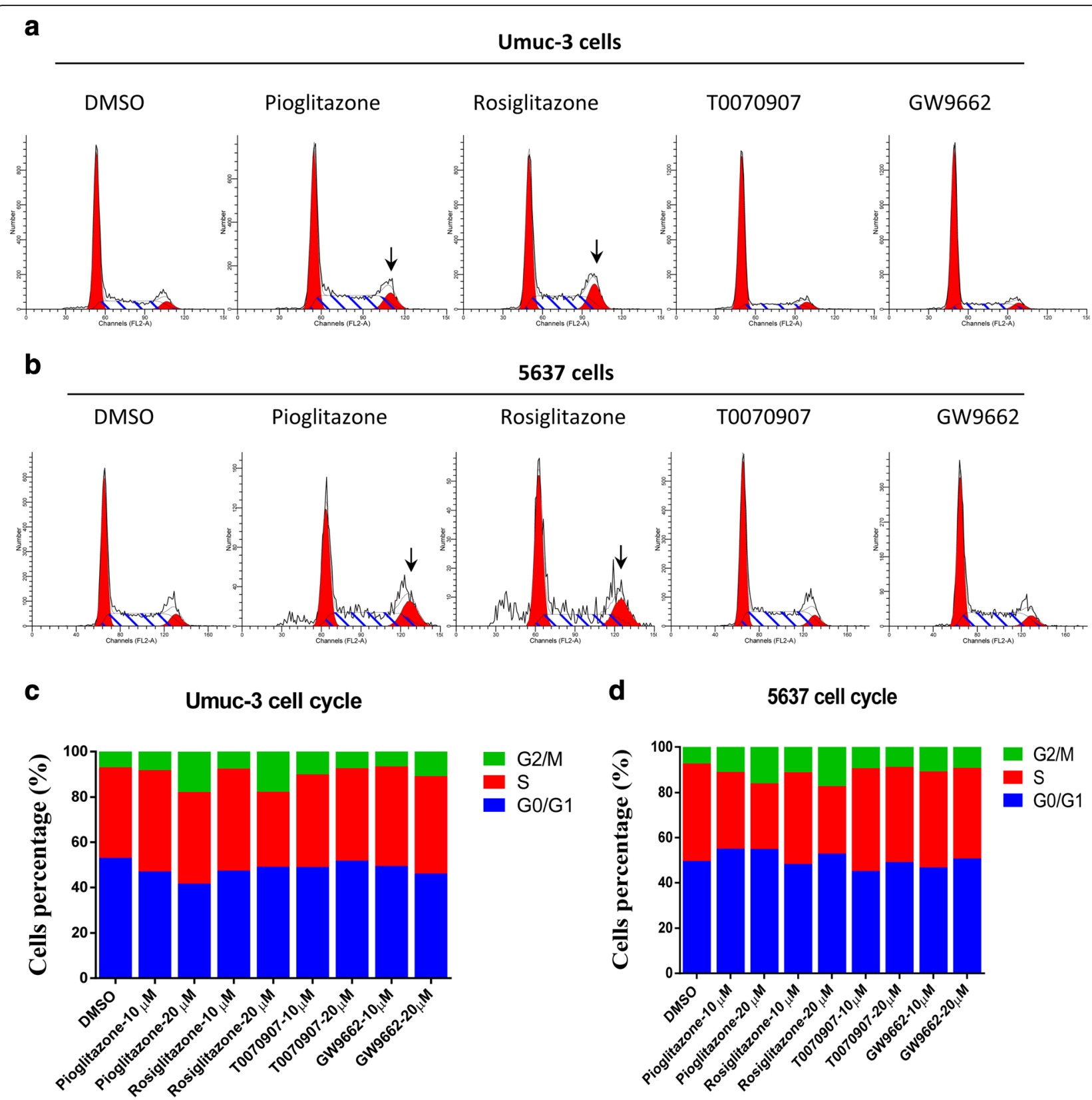

Fig. 3 PPARy agonists induced cell cycle G2 arrest in bladder cancer cells. (a) Cell cycle determined with flow cytometry in Umuc-3 cells. (b) Cell cycle determined with flow cytometry in 5637 cells. (c) Cell cycle distribution Umuc-3 cells. (d) Cell cycle distribution in 5637 cells. Umuc-3 and 5637 cells were treated with pioglitazone, rosiglitazone, T0070907, and GW9662 (10, $20 \mu \mathrm{M})$ for $72 \mathrm{~h}$

(Fig. 5e). Together, these data suggests that PPARy activation inhibits PI3K-Akt signaling pathway in bladder cancer cells.

\section{PPARY activation suppresses bladder cancer through inhibiting Akt pathway}

To bridge the modulation of PPARyon PI3K-Akt pathway with its functional effects on the growth of bladder cancer cells, we next determined the Akt-modulated molecules that govern cell survival and apoptosis. Firstly, we validated that blockade of PI3K-Akt signaling pathway using the specific inhibitor of PI3K, Ly294002 and the highly selective inhibitor of Akt, MK2206 repressed proliferation of Umuc-3 cells in a dose-dependent manner (Fig. 6a). Also, Ly294002 and MK2206 induced remarkable apoptosis in the Umuc-3 cells (Fig. 6b), suggesting PI3K-Akt plays crucial role in growth control of bladder cancer cells.

In further, we confirmed the suppressive effect of PPAR $\gamma$ activation on Akt phosphorylation in bladder cancer with the subcutaneous tumor models. In parallel 


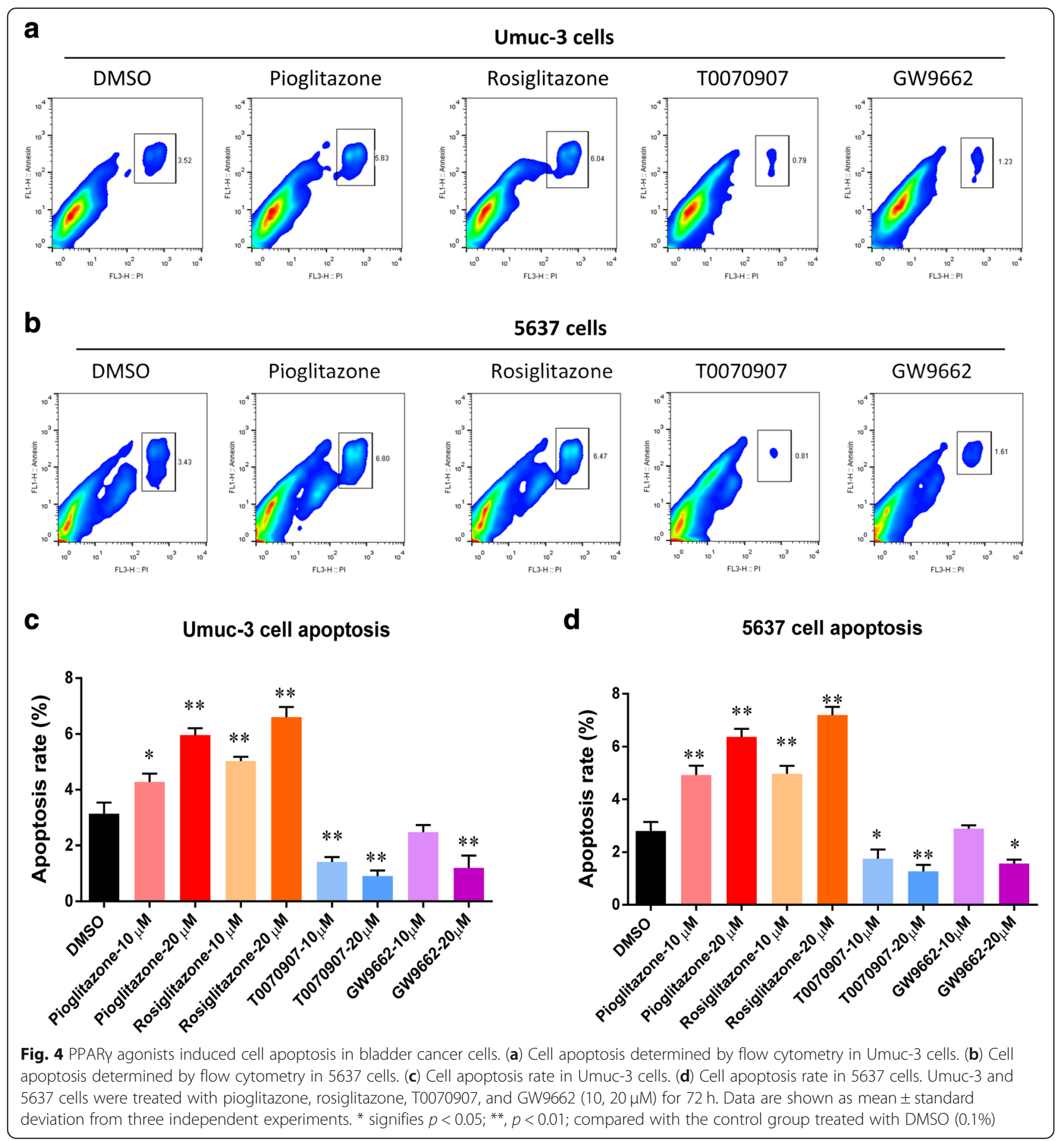

with the results from in vitro studies, treatment with rosiglitazone significantly hindered the growth of tumors that subcutaneously generated with Umuc-3 and 5637 cells (Fig. 6c). Importantly, we observed that PPAR $\gamma$ activation in the tumor tissues was in line with the expression of the target gene PTEN, but inversely correlated with the activation of Akt, as indicated by the phosphorylation of Akt (Ser473) and its downstream FoxO1 (Ser256) and Bcl2 (Ser70) (Fig. 6d).
In addition, the immunofluorescence staining showed that rosiglitazone induced translocation of PPARy from cytoplasm into nucleus indicating marked PPAR $\gamma$ activation in 5637 cancer cells (Fig. 7a). Simultaneously, the phosphorylation of forkhead transcription factor FoxO1 (Ser256) was significantly decreased, which resulted the cytoplasmic sequestration of FoxO1 and inactivated function of promoting cell cycle arrest and apoptosis. Finally, we further validated the association of PPAR $\gamma$ with the Akt-regulated downstream 


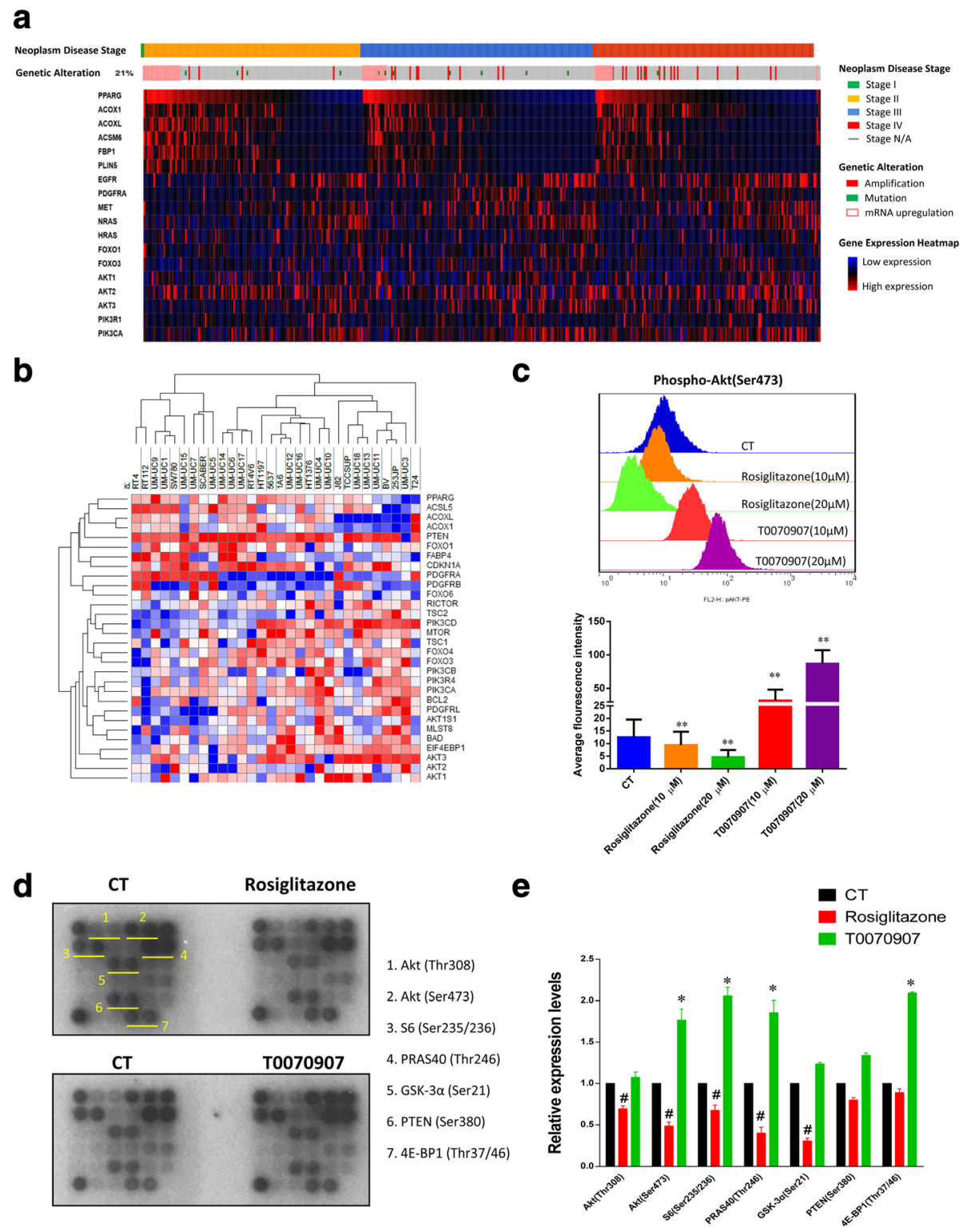

Fig. 5 PPARY activation inhibits PI3K-Akt signaling pathway in bladder cancer. (a) Heat Map of PPARG and PI3K-Akt associated genes in TCGA cases. (b) Hierarchical Clustering of PPARG and PI3K-Akt associated genes in 30 human bladder cancer cell lines. (c) Phosphorylation of Akt (Ser473) determined with flow cytometry. 5637 cells were treated with rosiglitazone and T0070907 (10, $20 \mu \mathrm{M})$ for $12 \mathrm{~h} .{ }^{*}$ signifies $p<0.05 ;{ }^{* *}, p<$ 0.01; compared with the control group treated with DMSO (0.1\%). (d) Proteomic array analysis on Akt signaling pathway. 5637 cells were treated with rosiglitazone and T0070907 $(20 \mu \mathrm{M})$ for $72 \mathrm{~h}$. (e) Quantitative analysis of proteomic array. Data are shown as mean \pm standard deviation. \#, $p$ $<0.05$ decreased when compared with the control $(C T) ;{ }^{*}, p<0.05$ increased when compared with the control

molecules that governing cell survival and apoptosis. Treatment with rosiglitazone significantly increased expression of PPARY and PTEN. In contrast, down-regulation of PPARy by T0070907 induced marked activation of Akt and the subsequent phosphorylation of Bad, FoxO1, and Bcl2; however, negatively regulated the cyclin dependent kinase inhibitor p21 Waf1/Cip1 (Fig. 7b). In aggregate, these data suggests that the inhibition of Akt signaling pathway might serve as an important mechanism underlying the suppression of bladder cancer by PPARy activation.

\section{Discussion}

Recent genomic analysis suggested potential risk of bladder cancer upon activation of PPAR $\gamma$ signaling pathway. PPARG was identified as a significant focal amplification specifically in bladder cancer by genome identification of significant targets in cancer (GISTIC) analysis [14]. The amplification and overexpression of PPARG occurred in about $40 \%$ MIBC cases [15]. Accumulating evidence implicates PPARG as a key gene in bladder cancer, but the functional effect of PPARG in tumor development are controversial. The 
a

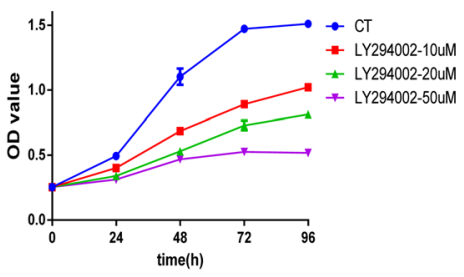

b
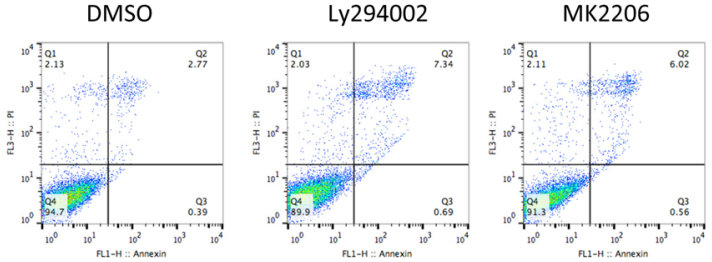
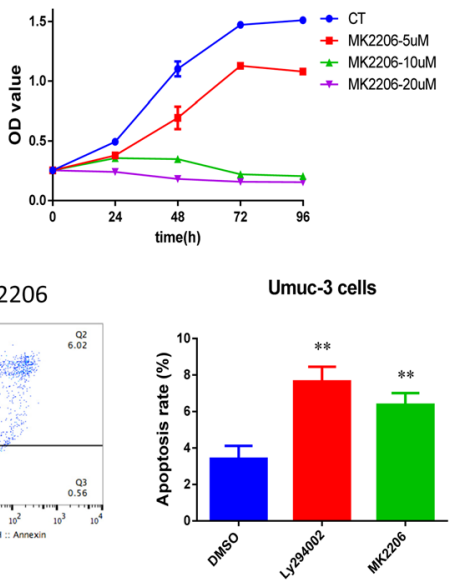

C
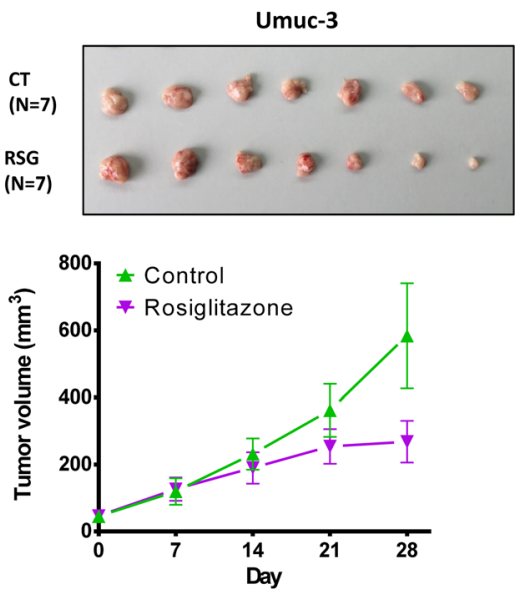

d
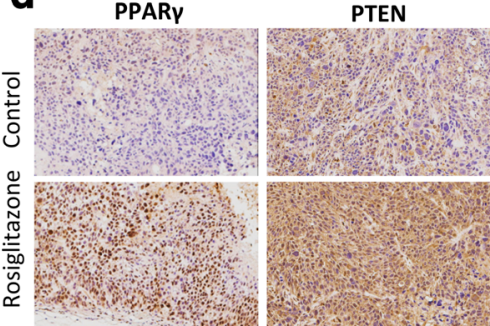

Phospho-Akt

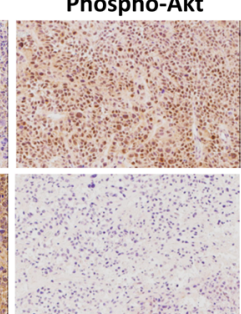

5637
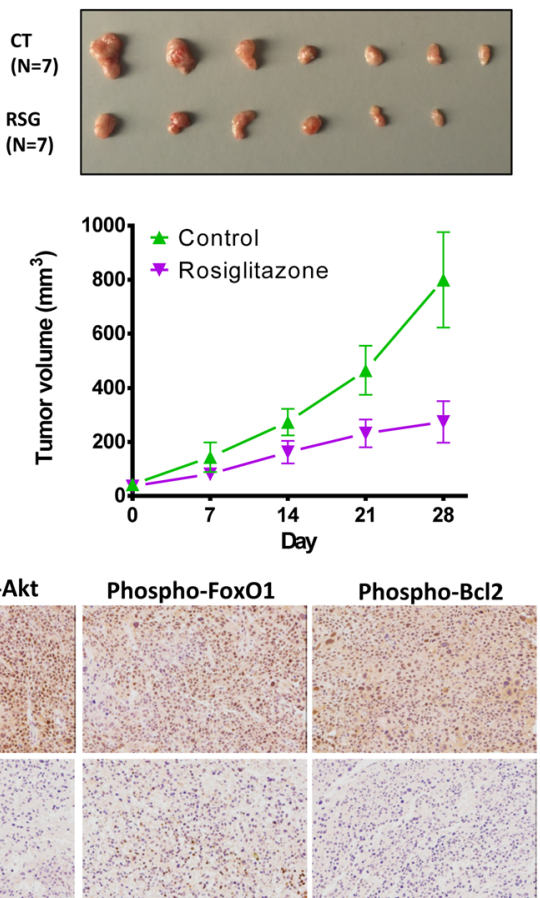

Fig. 6 PPARY activation suppresses bladder cancer through inhibiting Akt pathway. (a) Blockade of PI3K-Akt signaling pathway inhibited proliferation of bladder cancer cells. Umuc-3 cells were treated with Ly294002 (10, 20, $50 \mu \mathrm{M})$ and MK2206 (5, 10, $20 \mu \mathrm{M})$ for $96 \mathrm{~h}$. Cell proliferation was determined with CCK-8 every $24 \mathrm{~h}$. (b) Blockade of PI3K-Akt signaling pathway induced cell apoptosis in bladder cancer cells. Umuc-3 cells were treated with Ly294002 $(20 \mu \mathrm{M})$ and MK2206 $(10 \mu \mathrm{M})$ for $24 \mathrm{~h}$. Data are shown as mean \pm standard deviation from triplicate experiments. * signifies $p<0.05$; **, $p<0.01$; compared with the control group treated with DMSO (0.1\%). (c) Rosiglitazone hindered the growth of subcutaneous tumors generated with Umuc-3 and 5637 cells in nude mice $(n=7)$. (d) IHC staining of PPARY, PTEN, and the phosphorylation of Akt (Ser473),

FoxO1 (Ser256) and Bcl2 (Ser70) in subcutaneous tumors

pro-tumorigenic and anti-tumorigenic role of PPARG was also found in colon cancer, breast cancer, prostate cancer, lung cancer and many others [16]. In this study, we found MIBC patients from our cohort and the TCGA database markedly benefited from higher expression levels of PPARG with longer overall survival, suggesting the favorable action of PPARy in bladder cancer. In MIBC cohort and human bladder cancer cell lines, the expression of PPARG and its target genes were found inversely associated with the activation of PI3K-Akt pathway. Further experiments confirmed that pharmacological activation of PPAR $\gamma$ notably induced cell cycle arrest and apoptosis of bladder cancer cells, which was tightly related to the inhibition of signaling transduction in PI3K-Akt pathway. Our data suggested that PPARY activation suppressed bladder cancer through inhibiting PI3K-Akt signaling pathway (Fig. 7c). 


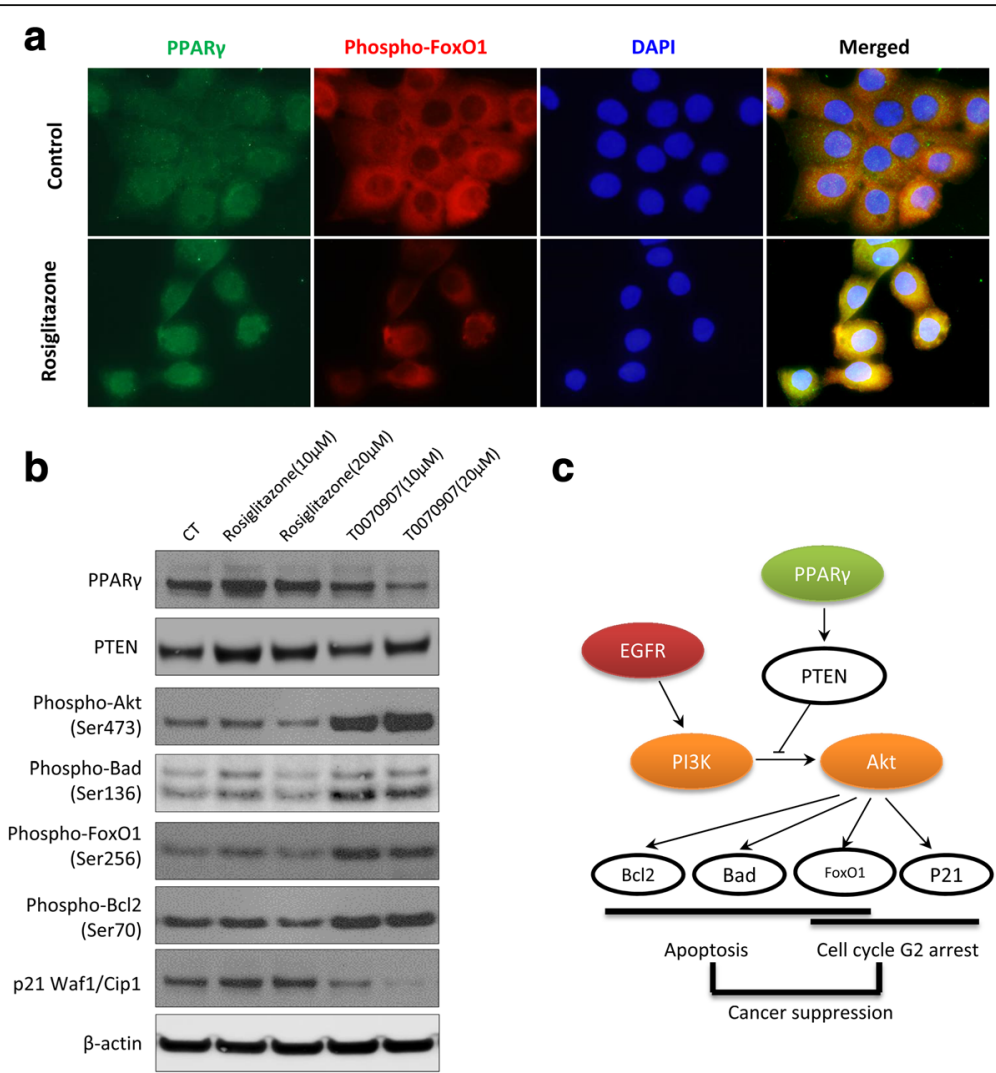

Fig. 7 PPARy activation suppresses signaling transduction that controls cell cycle and apoptosis in Akt pathway. (a) Immunofluorescence staining of PPARy and phospho-FoxO1 (Ser256) in 5637 cells. Cells seeded on cover slides were treated with solvent (0.1\%DMSO) or rosiglitazone (20 $\mu \mathrm{M})$ for $12 \mathrm{~h}$. (b) Western blotting of PPARy and downstream molecules in Akt pathway. 5637 cells were treated with rosiglitazone and T0070907 (10, $20 \mu \mathrm{M}$ ) for $72 \mathrm{~h}$. (c) Schematic illustration of the suppressive effect of PPARY activation against bladder cancer

PPARyis an important modulator of cellular energy metabolism that has been implicated in urothelial differentiation and malignancy. Rosiglitazone and other synthetic ligands of PPARY have been used as insulin sensitizers for the treatment of type 2 diabetes. However, undesirable side effects including weight gain, fluid retention, bone loss, and congestive heart failure have limited the use of thiazolidinediones. More importantly, the PPAR $\gamma$ agonist pioglitazone was shown to be associated with an increased risk of bladder cancer [17]. It was hypothesized that the effect of pioglitazone on promoting bladder cancer might be due to its PPAR $\alpha$ activity [18], as this was not observed with rosiglitazone, which is highly selective for PPARY [19]. The results of large population based studies indicated that pioglitazone was associated with an increased risk of bladder cancer, but the absence of an association with rosiglitazone suggested that the increased risk was drug specific and not a class effect [20]. In contrast, other population-based studies indicated that pioglitazone use was not associated with an increased risk of bladder cancer [21], or there was even trends of decreased bladder cancer [22]. On the other hand, another new class of PPAR $\gamma$ specific agonists, PPAR $\gamma$-active DIM-Cs significantly inhibited bladder tumorigenesis [23]. In line with previous studies, our data also suggested that PPAR $\gamma$ activation by agonists significantly suppressed bladder tumor growth in vitro and in vivo.

The regulation of PI3K by PPARy from previous studies are also controversial. It was reported that rosiglitazone can activate PI3K-Akt through PPAR $\gamma$-dependent biosynthesis of VEGF and leptin [24, 25]. On the contrary, PPAR $\gamma$ agonists were found to upregulate PTEN, subsequently inhibiting the PI3K-Akt signaling pathway in lung cancer cells [26]. Previous study also indicated that the tumor suppressor and anti-inflammatory actions of PPAR $\gamma$ agonists were mediated via upregulation of PTEN in Caco2 colorectal cancer cells and MCF7 breast cancer cells [27]. PTEN has been identified as lost or mutated in several sporadic and heritable cancer types. Experimental studies have indicated that PTEN is a non-redundant phosphatase that is essential for regulating the highly oncogenic pro-survival PI3K-Akt signaling pathway [28]. In bladder cancer, PI3K pathway alterations are commonly observed [29], and the inactivation of PTEN has also been implicated in the development of 
bladder cancer [30]. For other cancer types, some small molecule agonist of PPAR $\gamma$ has been shown to reduce the phosphorylation of Akt at Ser473 and exert therapeutic effects [31, 32]. In this study, we also observed the negative correlation between the expression of PTEN and Akt activation under the treatment of PPARY agonists. However, in addition to PPAR $\gamma$, numerous factors have been demonstrated to upregulate PTEN transcription including IGF-2, EGR-1, and p53 [28]. Therefore, as a limitation in this study, it was difficult to conclude whether the anti-cancer effect of PPAR $\gamma$ activation was dependent on PTEN without gene-knockout validations.

In addition, the transactivation of PPARG involves interaction with coactivators such as retinoid $\mathrm{X}$ receptors (RXRs), and the transrepression involves interference with other signal transduction pathways including NFkB, STAT, and AP1 [33]. The crosstalk of PPAR $\gamma$ signaling transduction with these factors determines the fate of cellular pathogenesis. From the view of tumor microenvironment, other biological functions of PPAR $\gamma$ may be also involved in bladder cancer. For example, a recent study characterized diverse genetic alterations in MIBC that convergently lead to constitutive activation of PPAR $\gamma / \mathrm{RXR} \alpha$ and result in immunosurveillance escape by inhibiting CD8+ T-cell recruitment [15].Thus, the outcome of PPAR $\gamma$ agonists use might be variable in different circumstances of tumorigenesis including cancer types and disease stages. In the present study, we focused on the intrinsic changes of bladder cancer cells that induced by the alteration of PPAR $\gamma$. Based on the analysis of PI3K-Akt pathway in TCGA cohort and 30 human bladder cell lines (Fig. 5a and b), a group of genes governing cell survival and apoptosis were identified inversely correlated with PPAR $\gamma$ transactivation. We further validated in bladder cancer Umuc-3 and 5637 cells that phosphorylation of $\mathrm{Bcl} 2$, Bad, and FoxO1 was consistently repressed by PPARy agonist rosiglitazone, but enhanced by the inverse agonist T0070907. The basal cellular transactivation of PPARG may affect the responses of cells to PPARY agonists, but our data suggested that the cell lines with low and medium basal levels of PPARG expression were both sensitive to the PPAR $\gamma$ agonists. Similarly, other investigators also found that PPAR $\gamma$ antagonist GW9662 recovered the cell cycle arrest induced by simvastatin in T24, 5637, and EJ cells [12]. Another high-affinity ligand for PPAR $\gamma$, ciglitazone, induced G2/M cell cycle arrest characterized by an overexpression of p53, p21 and p27 in RT4 cells, and also triggered apoptosis in T24 cells [34]; however, the cell cycle arrest and induction of apoptosis was proposed through up-regulation of TRAIL that was independent of PPARy activation [35]. Taken together, though experimental studies showed promising anti-malignant effect of PPAR $\gamma$ agonists, due to the heterogeneity of this malignancy, more precise characterization on both genetic and epigenetic alterations in patients as well as cell lines is warranted to better understand the multifacet role of PPAR $\gamma$ in bladder cancer.

\section{Conclusions}

This study demonstrated the tumor-suppressive effect of PPAR $Y$ agonists rosiglitazone and pioglitazone in bladder cancer. We showed that PPAR $\gamma$ was a favorable prognostic factor in patients with bladder cancer. PPAR $\gamma$ activation by rosiglitazone and pioglitazone markedly induced cell cycle G2 arrest and apoptosis in bladder cancer cells, which resulted in inhibition of cell proliferation in vitro and suppression of tumor growth in vivo. The underlying mechanism involved inhibition of PI3K-Akt pathway. This study suggested that transactivation of PPAR $\gamma$ could be served as a potential strategy for the chemoprevention and therapeutic treatment of bladder cancer.

\section{Additional file}

Additional file 1: Table S1. The information of Human bladder cancer cases used in tissue microarray (TMA). (PDF 59 kb)

\section{Abbreviations}

ANOVA: one-way analysis of variance; ATCC: American type culture collection; CCK-8: Cell counting Kit-8; FGFR3: Fibroblast growth factor receptor 3; GISTIC: genome identification of significant targets in cancer; IHC: Immunohistochemistry; MIBC: muscle-invasive bladder cancer; PI: propidium iodide; PI3K: Phosphoinositide 3-kinase; PPARY: Peroxisome proliferator-activated receptor gamma; PTEN: Phosphatase and tensin homolog; TCGA: The cancer genome atlas; TMA: tissue microarray

\section{Acknowledgements}

Not applicable.

\section{Funding}

This work was supported by Guangdong Science and Technology Project of China (Award Number: 2016ZC0064; Recipient: Chengyong Lei). The funders had no role in study design, data collection and analysis, decision to publish, or preparation of manuscript.

\section{Availability of data and materials}

The datasets used and analyzed during the current study are available from the corresponding author on reasonable request. The provisional TCGA muscleinvasive urothelial carcinoma data is available from the Broad Institute TCGA Genome Data Analysis Center (https://gdc.cancer.gov) and the Broad Institute GDAC FireBrowse portal (http://gdac.broadinstitute.org). The 412 muscle-invasive bladder cancers (MIBC) were previously analyzed [7]. The analysis on PPARG and PI3K-Akt was performed through cBioPortal for Cancer Genomics platform [36]. The RNA-seq data for 30 human bladder cancer cell lines is available on the Gene Expression Omnibus (GEO) with the accession number GSE97768. The samples were grouped by hierarchical clustering of columns using the Morpheus software package (https://software.broadinstitute.org/morpheus/).

\section{Authors' contributions}

$\mathrm{CL}, \mathrm{SL}$, and WW conceived and designed the experiments, SL, WW, HW and $Y Z$ performed the experiments, SL and WW analyzed the results, HW and $Y Z$ contributed reagents/materials/analysis tools, $\mathrm{CL}, \mathrm{SL}, \mathrm{WW}, \mathrm{HW}$ and $\mathrm{YZ}$ contributed to the writing of the manuscript. All authors reviewed the manuscript. All authorsread and approved the final manuscript. 


\section{Ethics approval and consent to participate}

For the use of human tissue for research purposes, a written consent to participate in the study has been obtained from patients. The study with human tissue was approved by the Medical Ethics Committee of Taizhou Hospital Zhejiang Province. The protocol for animal study was approved by the Institutional Animal Care and Use Committee (IACUC) of Southern Medical University and in correspondence with the principals and procedures outlined in the National Institute of Health $(\mathrm{NIH})$ Guide for the Care and Use of Animals under Assurance Number A3873-1.

\section{Consent for publication}

Not applicable.

\section{Competing interests}

The authors declare that they have no competing interests.

\section{Publisher's Note}

Springer Nature remains neutral with regard to jurisdictional claims in published maps and institutional affiliations.

\section{Author details}

'Department of Urology, Nanfang Hospital, Southern Medical University, No.1838 North of Guangzhou Avenue, Guangzhou 510515, China. 2Department of Pathology, General Hospital of Southern Theater Command, PLA, Guangzhou 510010, China. ${ }^{3}$ Department of Obstetrics and Gynecology, Center for Reproductive Medicine, Nanfang Hospital, Southern Medical University, Guangzhou 510515, China.

Received: 22 August 2018 Accepted: 1 March 2019

Published online: 07 March 2019

\section{References}

1. Collaborators GDIIP. Global, regional, and national incidence, prevalence, and years lived with disability for 310 diseases and injuries, 1990-2015: a systematic analysis for the global burden of disease study 2015. Lancet. 2016;388(10053):1545-602.

2. Chavan S, Bray F, Lortet-Tieulent J, Goodman M, Jemal A. International variations in bladder cancer incidence and mortality. Eur Urol. 2014;66(1): 59-73.

3. Choi W, Czerniak B, Ochoa A, Su X, Siefker-Radtke A, Dinney C, McConkey DJ. Intrinsic basal and luminal subtypes of muscle-invasive bladder cancer Nat Rev Urol. 2014;11(7):400-10.

4. Biton A, Bernard-Pierrot I, Lou Y, Krucker C, Chapeaublanc E, Rubio-Perez C, Lopez-Bigas N, Kamoun A, Neuzillet Y, Gestraud P, Grieco L, Rebouissou S, de Reynies A, Benhamou S, Lebret T, Southgate J, Barillot E, Allory Y, Zinovyev A, Radvanyi F. Independent component analysis uncovers the landscape of the bladder tumor transcriptome and reveals insights into luminal and basal subtypes. Cell Rep. 2014;9(4):1235-45.

5. Cancer Genome Atlas Research N. Comprehensive molecular characterization of urothelial bladder carcinoma. Nature. 2014;507(7492): 315-22.

6. Karkera JD, Cardona GM, Bell K, Gaffney D, Portale JC, Santiago-Walker A, Moy CH, King P, Sharp M, Bahleda R, Luo FR, Alvarez JD, Lorenzi MV, Platero SJ. Oncogenic characterization and pharmacologic sensitivity of activating fibroblast growth factor receptor (FGFR) genetic alterations to the selective FGFR inhibitor Erdafitinib. Mol Cancer Ther. 2017;16(8):1717-26.

7. Robertson AG, Kim J, Al-Ahmadie H, Bellmunt J, Guo G, Cherniack AD Hinoue T, Laird PW, Hoadley KA, Akbani R, Castro MAA, Gibb EA, Kanchi RS, Gordenin DA, Shukla SA, Sanchez-Vega F, Hansel DE, Czerniak BA, Reuter VE, Su X, de Sa Carvalho B, Chagas VS, Mungall KL, Sadeghi S, Pedamallu CS, Lu Y, Klimczak LJ, Zhang J, Choo C, Ojesina Al, Bullman S, Leraas KM, Lichtenberg TM, Wu CJ, Schultz N, Getz G, Meyerson M, Mills GB, McConkey DJ, Network TR, Weinstein JN, Kwiatkowski DJ, Lerner SP. Comprehensive molecular characterization of muscle-invasive bladder Cancer. Cell. 2017; 171(3):540-556 e525.

8. Choi W, Porten S, Kim S, Willis D, Plimack ER, Hoffman-Censits J, Roth B, Cheng T, Tran M, Lee IL, Melquist J, Bondaruk J, Majewski T, Zhang S, Pretzsch S, Baggerly K, Siefker-Radtke A, Czerniak B, Dinney CP, McConkey DJ. Identification of distinct basal and luminal subtypes of muscle-invasive bladder cancer with different sensitivities to frontline chemotherapy. Cancer Cell. 2014;25(2):152-65.
9. Warrick JI, Walter V, Yamashita H, Chung E, Shuman L, Amponsa VO, Zheng Z, Chan W, Whitcomb TL, Yue F, lyyanki T, Kawasawa YI, Kaag M, Guo W, Raman JD, Park JS, DeGraff DJ. FOXA1, GATA3 and PPAR cooperate to drive luminal subtype in bladder Cancer: a molecular analysis of established human cell lines. Sci Rep. 2016;6:38531.

10. Yang DR, Lin SJ, Ding XF, Miyamoto H, Messing E, Li LQ, Wang N, Chang C. Higher expression of peroxisome proliferator-activated receptor gamma or its activation by agonist thiazolidinedione-rosiglitazone promotes bladder cancer cell migration and invasion. Urology. 2013;81(5):1109.e1101-6.

11. Goldstein JT, Berger AC, Shih J, Duke FF, Furst L, Kwiatkowski DJ, Cherniack AD, Meyerson M, Strathdee CA. Genomic activation of PPARG reveals a candidate therapeutic Axis in bladder Cancer. Cancer Res. 2017;77(24):698798.

12. Wang G, Cao R, Wang Y, Qian G, Dan HC, Jiang W, Ju L, Wu M, Xiao Y, Wang $X$. Simvastatin induces cell cycle arrest and inhibits proliferation of bladder cancer cells via PPARgamma signalling pathway. Sci Rep. 2016;6: 35783.

13. Yan S, Yang $X$, Chen T, Xi Z, Jiang $X$. The PPARgamma agonist Troglitazone induces autophagy, apoptosis and necroptosis in bladder cancer cells. Cancer Gene Ther. 2014;21(5):188-93.

14. Zack TI, Schumacher SE, Carter SL, Cherniack AD, Saksena G, Tabak B, Lawrence MS, Zhsng CZ, Wala J, Mermel CH, Sougnez C, Gabriel SB, Hernandez B, Shen H, Laird PW, Getz G, Meyerson M, Beroukhim R. Pancancer patterns of somatic copy number alteration. Nat Genet. 2013;45(10): 1134-40.

15. Korpal M, Puyang X, Jeremy Wu Z, Seiler R, Furman C, Oo HZ, Seiler M, Irwin S, Subramanian V, Julie Joshi J, Wang CK, Rimkunas V, Tortora D, Yang H, Kumar N, Kuznetsov G, Matijevic M, Chow J, Kumar P, Zou J, Feala J, Corson L, Henry R, Selvaraj A, Davis A, Bloudoff K, Douglas J, Kiss B, Roberts M, Fazli L, Black PC, Fekkes P, Smith PG, Warmuth M, Yu L, Hao MH, Larsen N, Daugaard M, Zhu P. Evasion of immunosurveillance by genomic alterations of PPARgamma/RXRalpha in bladder cancer. Nat Commun. 2017:8(1):103.

16. Peters JM, Shah YM, Gonzalez FJ. The role of peroxisome proliferatoractivated receptors in carcinogenesis and chemoprevention. Nat Rev Cancer. 2012;12(3):181-95.

17. Dormandy JA, Charbonnel B, Eckland DJ, Erdmann E, Massi-Benedetti M, Moules IK, Skene AM, Tan MH, Lefebvre PJ, Murray GD, Standl E, Wilcox RG, Wilhelmsen L, Betteridge J, Birkeland K, Golay A, Heine RJ, Koranyi L, Laakso M, Mokan M, Norkus A, Pirags V, Podar T, Scheen A, Scherbaum W, Schernthaner G, Schmitz O, Skrha J, Smith U, Taton J, Investigators PR. Secondary prevention of macrovascular events in patients with type 2 diabetes in the PROactive study (PROspective pioglitAzone clinical trial in macroVascular events): a randomised controlled trial. Lancet. 2005;366(9493): 1279-89.

18. Sakamoto J, Kimura H, Moriyama S, Odaka H, Momose $Y$, Sugiyama Y, Sawada $\mathrm{H}$. Activation of human peroxisome proliferator-activated receptor (PPAR) subtypes by pioglitazone. Biochem Biophys Res Commun. 2000; 278(3):704-11.

19. Tannehill-Gregg SH, Sanderson TP, Minnema D, Voelker R, Ulland B, Cohen SM, Arnold LL, Schilling BE, Waites CR, Dominick MA. Rodent carcinogenicity profile of the antidiabetic dual PPAR alpha and gamma agonist muraglitazar. Toxicol Sci. 2007;98(1):258-70.

20. Tuccori M, Filion KB, Yin H, Yu OH, Platt RW, Azoulay L. Pioglitazone use and risk of bladder cancer: population based cohort study. BMJ. 2016;352:i1541.

21. Lewis JD, Habel LA, Quesenberry CP, Strom BL, Peng T, Hedderson MM, Ehrlich SF, Mamtani R, Bilker W, Vaughn DJ, Nessel L, Van Den Eeden SK Ferrara A. Pioglitazone use and risk of bladder Cancer and other common cancers in persons with diabetes. JAMA. 2015;314(3):265-77.

22. Erdmann E, Harding S, Lam H, Perez A. Ten-year observational follow-up of PROactive: a randomized cardiovascular outcomes trial evaluating pioglitazone in type 2 diabetes. Diabetes Obes Metab. 2016;18(3):266-73.

23. Kassouf W, Chintharlapalli S, Abdelrahim M, Nelkin G, Safe S, Kamat AM. Inhibition of bladder tumor growth by 1,1-bis(3'-indolyl)-1-(psubstitutedphenyl)methanes: a new class of peroxisome proliferatoractivated receptor gamma agonists. Cancer Res. 2006;66(1):412-8.

24. Ku YH, Cho BJ, Kim MJ, Lim S, Park YJ, Jang HC, Choi SH. Rosiglitazone increases endothelial cell migration and vascular permeability through Akt phosphorylation. BMC Pharmacol Toxicol. 2017;18(1):62.

25. Terrasi M, Bazan V, Caruso S, Insalaco L, Amodeo V, Fanale D, Corsini LR, Contaldo C, Mercanti A, Fiorio E, Lo Re G, Cicero G, Surmacz E, Russo A. Effects of PPARgamma agonists on the expression of leptin and vascular 
endothelial growth factor in breast cancer cells. J Cell Physiol. 2013;228(6): $1368-74$.

26. To KKW, Wu WKK, Loong HHF. PPARgamma agonists sensitize PTENdeficient resistant lung cancer cells to EGFR tyrosine kinase inhibitors by inducing autophagy. Eur J Pharmacol. 2018;823:19-26.

27. Patel L, Pass I, Coxon P, Downes CP, Smith SA, Macphee CH. Tumor suppressor and anti-inflammatory actions of PPARgamma agonists are mediated via upregulation of PTEN. Curr Biol. 2001;11(10):764-8.

28. Salmena L, Carracedo A, Pandolfi PP. Tenets of PTEN tumor suppression. Cell. 2008;133(3):403-14.

29. Platt FM, Hurst CD, Taylor CF, Gregory WM, Harnden P, Knowles MA. Spectrum of phosphatidylinositol 3-kinase pathway gene alterations in bladder cancer. Clin Cancer Res. 2009;15(19):6008-17.

30. Ahmad I, Morton JP, Singh LB, Radulescu SM, Ridgway RA, Patel S, Woodgett J, Winton DJ, Taketo MM, Wu XR, Leung HY, Sansom OJ. Betacatenin activation synergizes with PTEN loss to cause bladder cancer formation. Oncogene. 2011;30(2):178-89.

31. Sawayama H, Ishimoto T, Watanabe M, Yoshida N, Sugihara H, Kurashige J, Hirashima K, Iwatsuki M, Baba Y, Oki E, Morita M, Shiose Y, Baba H. Small molecule agonists of PPAR-gamma exert therapeutic effects in esophageal cancer. Cancer Res. 2014;74(2):575-85.

32. Xu M, Yang H, Zhang Q, Lu P, Feng Y, Geng X, Zhang L, Jia X. Alphatocopherol prevents esophageal squamous cell carcinoma by modulating PPARgamma-Akt signaling pathway at the early stage of carcinogenesis. Oncotarget. 2017;8(56):95914-30.

33. Fucci A, Colangelo T, Votino C, Pancione M, Sabatino L, Colantuoni V. The role of peroxisome proliferator-activated receptors in the esophageal, gastric, and colorectal cancer. PPAR Res. 2012;2012:242498.

34. Plissonnier ML, Fauconnet S, Bittard H, Lascombe I. The antidiabetic drug ciglitazone induces high grade bladder cancer cells apoptosis through the up-regulation of TRAIL. PLoS One. 2011;6(12):e28354.

35. Plissonnier ML, Fauconnet S, Bittard H, Lascombe I. Insights on distinct pathways of thiazolidinediones (PPARgamma ligand)-promoted apoptosis in TRAIL-sensitive or -resistant malignant urothelial cells. Int J Cancer. 2010; 127(8):1769-84.

36. Cerami E, Gao J, Dogrusoz U, Gross BE, Sumer SO, Aksoy BA, Jacobsen A, Byrne CJ, Heuer ML, Larsson E, Antipin Y, Reva B, Goldberg AP, Sander C, Schultz N. The cBio cancer genomics portal: an open platform for exploring multidimensional cancer genomics data. Cancer Discov. 2012;2(5):401-4.

Ready to submit your research? Choose BMC and benefit from:

- fast, convenient online submission

- thorough peer review by experienced researchers in your field

- rapid publication on acceptance

- support for research data, including large and complex data types

- gold Open Access which fosters wider collaboration and increased citations

- maximum visibility for your research: over $100 \mathrm{M}$ website views per year

At $\mathrm{BMC}$, research is always in progress.

Learn more biomedcentral.com/submissions 